$\xi=-1$

\title{
Higher education selection using simple additive weighting
}

\author{
Nur Aminudin ${ }^{1}$, Miftachul Huda ${ }^{2}$, Ahmad Kilani ${ }^{2}$, Wan Hassan Wan Embong ${ }^{2}$, Ahmad Marzuki Mohamed ${ }^{2}$, \\ Bushrah Basiron ${ }^{2}$, Siti Suhaila Ihwani ${ }^{2}$, Sulaiman Shakib Mohd Noor ${ }^{2}$, Kamarul Azmi Jasmi ${ }^{2}$, \\ Jimaain Safar ${ }^{2}$, Natalie L. Ivanova ${ }^{3}$, Andino Maseleno ${ }^{1,4}{ }^{*}$, Agus Triono ${ }^{1}$, Nungsiati ${ }^{1}$ \\ ${ }^{I}$ Department of Information Systems, STMIK Pringsewu, Lampung, Indonesia \\ ${ }^{2}$ Faculty of Social Sciences and Humanities, Universiti Teknologi Malaysia, Malaysia \\ ${ }^{3}$ Tyumen Industrial University, Russia \\ ${ }^{4}$ Institute of Informatics and Computing Energy, Universiti Tenaga Nasional, Malaysia \\ *Corresponding author E-mail: andimaseleno@gmail.com
}

\begin{abstract}
The process of selecting a college should be based on the capabilities and needs of the community. When society is faced with a large selection of college criteria and most societies are confused about choosing the appropriate college for themselves and the job demands. From this it was made a decision support system aimed at helping the community to choose a college that suits the ability and demands of the work. Decision support system plays a role in helping people get the right recommendations in the selection of universities. This decision support system is also designed to help the community to choose a college that suits their needs so that the public is not confused because of the many criteria of universities faced by the community because the admin already has recommendations according to the needs of the community by using Simple Additive Weighting (SAW) method.
\end{abstract}

Keywords: Higher Education; Student; Simple Additive Weighting.

\section{Introduction}

\subsection{Background}

In Indonesia, the number of universities continues to experience growth both public and private class. The growth of several universities in Indonesia indicates that the importance of knowledge gained for the provision of life or to find a job [1-3]. The looking view with visibility every year seems significant to elucidate the core point in enabling the number of students to get easily in continuing their learning enhancement [4-6]. In Indonesia, the number of education intuition has known three levels which needs to fulfill the requirements [7-9]. In order to access the learning enhancement among the learners, there should be underlined in giving insights into following the compulsory programs offered through the number of initiatives [10-12]. It is necessary to look into the model of compulsory education program one of which is Nine years [13-15]. It includes six years in Elementary School (SD), three years in Junior High School (SMP), and three years in High School or Vocational High School (SMK), although only required by Nine school year many students who continue to college level. In addition, the main issue would be viewed into the way in making decision experienced by high school students in determining the selection of majors in the world of education for example in the determination of majors in universities [16-18]. The particular attention with accessing both cooperative and competitive alliance would need to enhance to give insights into performance value [19-21]. This initiative is entirely a particular concern in preventing the valuable insights towards the lack of information about the particular information from wide range of objects including department and students [22-24]. It refers to the commitment with awareness towards interests, talents and abilities in enabling them to determine their majors based solely on parental choice through following the course [25-27]. Attempts to particularly choose the encouragement with knowing the department itself should do with preparing to tackle the difficulties [28-30]. Feeling with enabling the wide range of lessons learned to follow refers to expand the particular direction which could consequently be expanded into undergoing lectures more effective [31-33]. However, the number of challenges could be viewed such as lazy, unserious effort, and thus it is necessary to avoid needed system, which could assist the students in solving problems in determining the majors in accordance with the interests and specified criteria [34-36].

In line with elucidating the selection of the best colleges, it is necessary to get access in obtaining the interactive system with incorporating the basis of needs and interests among the students [3739]. The wide range of getting the desired criteria refers to obtain the quality of results and maximum learning [40-42]. Attempts to assist to maximize the decision support system become a pivotal value to deliver the interactive portion towards decision makers in giving update about particular information [43-45].

The model used in this decision support system model is SAW, because SAW is chosen because it can determine the weight value for each attribute, then proceed with the selection process which will select the best alternative from the number of alternatives, in this case the alternative is the best university based on the criteria specified.

\subsection{Problem formulation}

Based on the background of the above problem then the formulation of the problem are: 
1) How to determine criteria for university selection for the community?

2) How is the application of the Simple Additive Weighting (SAW) method to the decision support system to determine the college for the community?

\subsection{Boundaries}

In order that the discussion does not deviate from the underlying problems that have been formulated, there may be limitations as follows:

1) Criteria that become priority in determining Higher Education are academic achievement, lecturer, extracurricular, accreditation status, facility availability, campus scholarship.

2) The method used is Simple Additive Weighting (SAW)

3) The decision support system determines the best university.

4) This discussion is carried out only to discuss the selection of the best university election for the community.

\subsection{Aims}

The purpose of this study is to applying SAW method in determining university based on criteria and increasing knowledge about Simple Additive Weighting method.

\subsection{Benefits}

As for the benefits provided in this research is:

1) Make it easier in determining the best college for the community.

2) As a useful information for the community in its application.

3) Minimize the time in doing determine college selection.

\section{Literature review}

\subsection{Decision support system}

The significant effort to expand taking a good decision should be widely engaged into the several stages of the process within decision-making [46-48]. The decision process goes through the following steps:

1) Stage of understanding (Intelligence Phase) This stage is the process of tracking and detecting the scope of problematic and problem recognition process. The input data is obtained, processed and tested in order to identify the problem.

2) Design Phase (Design Phase)

In this stage the decision maker finds, develops and analyzes all possible solutions through modeling that can represent the real conditions of the problem. From this stage obtained the output of alternative document solutions. a) Phase of Choice (Choice Phase). In this stage the decision maker chooses one of the alternative solutions made at the design stage which is seen as the most appropriate action to overcome the current problem. From this stage obtained the solution documents and implementation plan. b) Implementation Phase (Implementation Phase). The decision maker runs the selected split action sequence at the choice stage. Successful implementation is marked by the answer to the problem faced, while the failure is marked still a problem that is being tried to overcome. From this stage obtained report on the implementation of the solution and the results.

Limitations of DSS are as follows:

1) There are some management abilities and human talents that can not be modeled, so the models that exist in the system do not all reflect the real problem.

2) The ability of a DSS is limited to the knowledge base it possesses (basic knowledge and basic model).

3) The processes that can be performed by DSS usually depend on the ability of the software it uses.
Multiple Attribute Decision Making (MADM) is a method used to find the optimal alternative of a number of alternatives with certain criteria. The essence of MADM is to determine the weight for each attribute, then proceed with the process of fixation that will solve the alternatives already given ".

\subsection{Definition of school}

School could be viewed into the tiered and continuous education unit to organize teaching and learning activities [3-4]. Schools can also be interpreted as institutions in which there are teachers, students, and administrative staff who have their respective duties in expediting the program [49-51].

In addition, the particular significance to look into the entire school refers to expand the basic role of institution or organization authorized to organize learning activities [52-54]. The wide range of skills might need to obtain the special attribution in aiming to produce the outcome with good knowledge and attitude [55-57]. Moreover, such components become a main priority among the schooling programs in deliberating the continuing schools to expand the skills [58-60]. As a result, the stage of achieving the abilities in consulting the potential value to train needs to gather continuing programs with higher level of work assigned into their skills [61].

\subsection{Decision support system criteria}

Decision support systems are designed specifically to support someone who must make certain decisions [51-52]. Here are some criteria of decision support systems:

1) Interactive

Decision support system has a communicative user interface, so users can access quickly and obtain the information needed.

2) Flexible

A decision-support system has as many as possible a variable input, the ability to process and deliver outsourcing the decision alternatives to the user.

3) Quality Data

A decision-support system has the ability to receive a quantifiable quantity that is objective in nature from the wearer, as an entity for the processing of data.

4) Expert procedure

The decision support system contains a planned procedure based on a formal or a group's or a group's expertise in solving a problem with a particular phenomenon.

\subsection{Resolution steps}

The steps of settlement in using the SAW method could be viewed into the following [52]:

1) Determine the criteria that will be used as a reference in decision making, namely $\mathrm{Ci}$.

2) Determine the match rating of each alternative on each criterion.

3) Make a decision matrix based on criterion (Ci), then do the normalization of matrix based on equation which is adjusted to attribute type (gain attribute and cost attribute) so obtained normalized matrix $\mathrm{R}$.

4) The final result is obtained from each ranking process that is the sum of normalized matrix multiplication $\mathrm{R}$ with weight vector to obtain the largest value chosen as the best alternative (Ai) as solution.

\section{Methodologies}

\subsection{Data collection}

Data collection is an activity to find data field that will be used to answer research problem .
a) Library study 
Library study is an activity of collecting data and information from various sources, such as books containing various kinds of theoretical studies that are needed by researchers, magazines, texts, historical stories, and documents.

b) Observation

Often observations are interpreted as a narrow activity, ie paying attention only to the naked eye.

\subsection{Data analysis}

Simple Additive Weighting (SAW) is one of the most popular methods used in Decision Support Systems. Selection of criteria for cases to be solved with the help of Decision Support System requires sharpening that is closely related to the problems at hand Things that become the reference for choosing the criteria should have a strong urgency with the problem to be sought solution. The number of criteria taken to analyze no definite provisions, but the more variations of criteria selected the better the results will be obtained.

The SAW method or often also known as the weighted summing method is looking for weighted sums of performance twigs on each alternative on all attributes [50-51]. The SAW method requires the process of normalizing the decision matrix $(\mathrm{X})$ to a scale comparable to all existing alternative ratings.

In the SAW method, criteria are perceived as benefit and cost criteria. Category criteria benefit or profit, if the criteria have a greater value then the better, while the criteria cost or cost the smaller the value then the better. Large and small values are seen from the relationship with the problems analyzed.

$r_{i j}=\frac{x_{i j}}{\max _{(x i j)}} j$ is benefit attribute

$r_{i j}=\frac{\min _{x i j}}{x_{i j}} j$ is cost attribute

Notes

rij = normalized performance rating score

xij $=$ attribute value of each criterion

Max $x i j=$ the greatest value of each criteria

Max $x i j=$ the smallest value of each criteria

Benefit $=$ if the greatest value is best

Cost $=$ if the smallest value is best

where rij is a performance twig $\mathrm{i}=1,2,3, \ldots, \mathrm{m}$ dan $\mathrm{j}=1,2,3, \ldots, \mathrm{m}$. Alternative preference values (vi) as :

$v_{i}=\sum_{j}^{n}=1^{w j r i j}$

Notes :

$\mathrm{V}_{\mathrm{I}}=$ ranking for any alternative

$\mathrm{W}_{\mathrm{j}}=$ value bobot criteria

$\mathrm{Rij}=$ normalized performance rating score

A larger $\mathrm{V}$ value indicates that Ai's alternatives are preferred.

\section{Implementation}

\subsection{Criteria and weight}

In this study, there are weights and criteria needed to determine which university will be selected as the best university. Table 1 shows criteria, table 2 shows weight value, table 3 shows academic achievement $(\mathrm{C} 1)$, table 4 shows master lecturer $(\mathrm{C} 2)$, table 5 shows extracurricular (C3), table 6 shows accreditation status (C4), table 7 shows facilities (C5), and table 8 shows scholarship (C6).

\begin{tabular}{lll}
\multicolumn{2}{c}{ Table 1: Criteria } \\
\hline Criteria & State & Score \\
\hline C1 & Academic achievement & 20 \\
C2 & Master Lecturer & 15 \\
C3 & Extracurricular & 15 \\
C4 & Accreditation Status & 10 \\
C5 & Facilities & 20 \\
C6 & Scholarship & 20 \\
& & 100 \\
\hline
\end{tabular}

Alternative:

$\mathrm{A} 1=\mathrm{ATP}$

\section{A2=STMIK Pringsewu}

\section{$\mathrm{A} 3=\mathrm{STIE}$}

\section{A4=STKIP}

\section{$\mathrm{A} 5=\mathrm{STIT}$}

Table 2: Weight Value

\begin{tabular}{ll} 
& Table 2: Weight Value \\
\hline Weight & Score \\
\hline Very Low & 1 \\
Low & 2 \\
Adequate & 3 \\
High & 4 \\
Very high & 5 \\
\hline
\end{tabular}

Table 3: Academic Achievement (C1)

\begin{tabular}{lll}
\hline Academic Achievement & Weight & Score \\
\hline Not important & SR & 1 \\
Very Not important & $\mathrm{R}$ & 2 \\
Important & $\mathrm{C}$ & 3 \\
Very important & $\mathrm{ST}$ & 5 \\
\hline
\end{tabular}

Table 4: Master Lecturer (C2)

\begin{tabular}{lll}
\hline Master Lecturer & Weight & Score \\
\hline Not important & $\mathrm{SR}$ & 1 \\
Very Not important & $\mathrm{R}$ & 2 \\
Important & $\mathrm{T}$ & 4 \\
Very important & $\mathrm{ST}$ & 5 \\
\hline
\end{tabular}

Table 5: Extracurricular (C3)

\begin{tabular}{lll}
\hline Extracurricular & Weight & Score \\
\hline Not important & SR & 1 \\
Important & T & 4 \\
Very important & ST & 5 \\
\hline
\end{tabular}

Table 6: Accreditation Status (C4)

\begin{tabular}{lll}
\hline Accreditation Status & Weight & Score \\
\hline Not important & SR & 1 \\
Important & C & 3 \\
Very important & ST & 5 \\
\hline
\end{tabular}

Table 7: Facilities (C5)

\begin{tabular}{lll}
\multicolumn{3}{c}{ Table 7: Facilities (C5) } \\
\hline Facilities & Weight & Score \\
\hline Very Not important & SR & 1 \\
Not important & $\mathrm{R}$ & 2 \\
Important & $\mathrm{C}$ & 3 \\
Very important & $\mathrm{ST}$ & 5 \\
\hline
\end{tabular}

Table 8: Scholarship (C6)

\begin{tabular}{lll}
\hline Scholarship & Weight & Score \\
\hline Very Not important & SR & 1 \\
Not important & $\mathrm{R}$ & 2 \\
Important & $\mathrm{T}$ & 4 \\
\hline
\end{tabular}




\begin{tabular}{|c|c|c|c|c|c|c|c|}
\hline No & Alternative & Criteria & & & & & \\
\hline & & $\begin{array}{l}\text { Academic } \\
\text { achievement }\end{array}$ & MasterLecturer & Extracurricular & $\begin{array}{l}\text { Accreditation } \\
\text { Status }\end{array}$ & Facilities & Scholarship \\
\hline 1 & ATP & 3 & 2 & 4 & 4 & 2 & 4 \\
\hline 2 & STMIK & 5 & 4 & 4 & 4 & 2 & 2 \\
\hline 3 & STIE & 1 & 5 & 1 & 1 & 5 & 4 \\
\hline 4 & STKIP & 2 & 2 & 3 & 3 & 2 & 4 \\
\hline 5 & STIT & 3 & 4 & 4 & 1 & 2 & 3 \\
\hline
\end{tabular}

Based on table 9 is converted into $\mathrm{X}$ decision matrix with data:

$X=\left\{\begin{array}{llllll}3 & 2 & 4 & 1 & 2 & 4 \\ 5 & 4 & 4 & 5 & 2 & 2 \\ 1 & 5 & 1 & 3 & 5 & 4 \\ 2 & 2 & 3 & 3 & 2 & 4 \\ 3 & 4 & 4 & 1 & 2 & 2\end{array}\right\}$

\subsection{Matrix normalization}

- A1

$\mathrm{R}_{1}=\frac{3}{\max \{2 ; 4 ; 5 ; 2 ; 4\}}=\frac{2}{5}=0,6$

$\mathrm{R}_{2}=\frac{2}{\max \{2 ; 4 ; 5 ; 2 ; 4\}}=\frac{2}{5}=0,4$

$\mathrm{R}_{3}=\frac{4}{\max \{4 ; 4 ; 1 ; 3 ; 4\}}=\frac{4}{4}=1$

$\mathrm{R}_{4}=\frac{1}{\max \{1 ; 5 ; 3 ; 3 ; 1\}}=\frac{1}{5}=0,2$

$\mathrm{R}_{5}=\frac{2}{\max \{2 ; 2 ; 5 ; 2 ; 2\}}=\frac{2}{5}=0,4$

$\mathrm{R}_{6}=\frac{4}{\max \{4 ; 2 ; 4 ; 4 ; 4\}}=\frac{4}{4}=1$

- $\mathrm{A} 2$

$\mathrm{R}_{11}=\frac{5}{\max \{3 ; 5 ; 1 ; 2 ; 3\}}=\frac{5}{5}=1$

$\mathrm{R}_{12}=\frac{4}{\max \{2 ; 4 ; 5 ; 2 ; 4\}}=\frac{4}{5}=0,8$

$\mathrm{R}_{13}=\frac{4}{\max \{4 ; 4 ; 1 ; 3 ; 4\}}=\frac{4}{4}=1$

$\mathrm{R}_{14}=\frac{5}{\max \{1 ; 5 ; 3 ; 3 ; 1\}}=\frac{5}{5}=1$

$\mathrm{R}_{15}=\frac{2}{\max \{2 ; 2 ; 5 ; 2 ; 2\}}=\frac{2}{5}=0,4$

$\mathrm{R}_{16}=\frac{2}{\max \{4 ; 2 ; 4 ; 4 ; 3\}}=\frac{2}{4}=0,5$

- A3

$\mathrm{R}_{21}=\frac{1}{\max \{3 ; 5 ; 1 ; 2 ; 3\}}=\frac{1}{5}=0,2$

$\mathrm{R}_{22}=\frac{5}{\max \{2 ; 4 ; 5 ; 2 ; 4\}}=\frac{5}{5}=1$

$\mathrm{R}_{23}=\frac{1}{\max \{4 ; 4 ; 1 ; 3 ; 4\}}=\frac{1}{5}=0,25$

$\mathrm{R}_{24}=\frac{3}{\max \{1 ; 5 ; 3 ; 3 ; 1\}}=\frac{3}{5}=0,6$

$\mathrm{R}_{25}=\frac{5}{\max \{2 ; 2 ; 5 ; 2 ; 2\}}=\frac{5}{5}=1$
$\mathrm{R}_{26}=\frac{4}{\max \{4 ; 2 ; 4 ; 4 ; 3\}}=\frac{4}{4}=1$

- A4

$\mathrm{R}_{31}=\frac{2}{\max \{3 ; 5 ; 1 ; 2 ; 3\}}=\frac{2}{5}=0,4$

$\mathrm{R}_{32}=\frac{2}{\max \{2 ; 4 ; 5 ; 2 ; 4\}}=\frac{2}{5}=0,4$

$\mathrm{R}_{33}=\frac{3}{\max \{4 ; 4 ; 1 ; 3 ; 4\}}=\frac{3}{5}=0,75$

$\mathrm{R}_{34}=\frac{3}{\max \{1 ; 5 ; 3 ; 3 ; 1\}}=\frac{3}{5}=0,6$

$\mathrm{R}_{35}=\frac{2}{\max \{2 ; 2 ; 5 ; 2 ; 2\}}=\frac{2}{5}=0,4$

$\mathrm{R}_{36}=\frac{4}{\max \{4 ; 2 ; 3 ; 4 ; 3\}}=\frac{4}{4}=1$

- A5

$\mathrm{R}_{41}=\frac{4}{\max \{3 ; 5 ; 1 ; 2 ; 3\}}=\frac{1}{5}=0,6$

$\mathrm{R}_{42}=\frac{4}{\max \{2 ; 4 ; 5 ; 2 ; 4\}}=\frac{4}{5}=0,8$

$\mathrm{R}_{43}=\frac{4}{\max \{4 ; 4 ; 1 ; 3 ; 4\}}=\frac{4}{4}=1$

$\mathrm{R}_{44}=\frac{1}{\max \{1 ; 5 ; 3 ; 3 ; 1\}}=\frac{1}{5}=0,2$

$\mathrm{R}_{45}=\frac{2}{\max \{2 ; 2 ; 5 ; 2 ; 2\}}=\frac{2}{5}=0,4$

$\mathrm{R}_{46}=\frac{3}{\max \{4 ; 2 ; 4 ; 4 ; 3\}}=\frac{3}{4}=0,75$

From the above calculation, then obtained normalized matrix as follows:

$r_{i j}=\left\{\begin{array}{cccccc}0,6 & 0,4 & 1 & 0,2 & 0,4 & 1 \\ 1 & 0,8 & 1 & 1 & 0,4 & 0,5 \\ 0,2 & 1 & 0,25 & 0,6 & 1 & 1 \\ 0,4 & 0,4 & 0,75 & 0,6 & 0,4 & 1 \\ 0,6 & 0,8 & 1 & 0,2 & 0,4 & 0,75\end{array}\right\}$

\subsection{Calculation}

$V_{I} \sum_{j=1}^{n} W_{j} \quad r_{i j}$

$\mathrm{V} 1=\{(0,6 \times 20)+(0,4 \times 15)+(1 \times 15)+(0,2 \times 10)+(0,4 \times 20)$

$+(1 \times 20)\}=63$

$\mathrm{V} 2=\{(1 \times 20)+(0,8 \times 15)+(1 \times 15)+(1 \times 10)+(0,4 \times 20)+(0$, $5 \times 20)\}=75$

$\mathrm{V} 3=\{(0,2 \times 20)+(1 \times 15)+(0,25 \times 15)+(0,6 \times 10)+(1 \times 20)$ $+(1 \times 20)\}=68,75$ 
$\mathrm{V} 4=\{(0,4 \times 20)+(0,4 \times 15)+(0,75 \times 15)+(0,6 \times 10)+(0,4 \times$

$20)+(1 \times 20)\}=59,25$

$\mathrm{V} 5=\{(0,6 \times 20)+(0,8 \times 15)+(1 \times 15)+(0,2 \times 10)+(0,4 \times 20)$

$+(0,75 \times 20)\}=64$

From the above calculation obtained the largest value on A2 so that the best alternative in other words STMIK Pringsewu is the best college.

\section{Conclusion}

Based on the results of design, implementation, and testing that have been done in the previous section, then in this study can be drawn conclusion: 1) Application of Simple Additive Weighting Method (SAW) is able to provide recommendation to user in the form of Higher Education based on the weight of predetermined criteria. 2) Simple Additive Weighting (SAW) method can be used to solve problems The selection of universities with the calculation of the method found that the most prioritized criteria are Accreditation compared to the other nine criteria such as academic achievement, non-academic achievement, overseas cooperation, domestic cooperation, Master lecturer, number of doctoral lecturer, lab facilities and scholarships.

Based on the results of research, there are some suggestions that the authors propose to develop this system more widely better as follows: 1) In solving multi criteria problem Simple Additive Weighting (SAW) method is not the only decision-making method that can be used, it is better to try to use other method or can combine two methods to support more effective decision. 2) Can be added other data that support the selection of colleges such as the addition of criteria. 3) To simplify and speed up the decisionmaking process, it is best to use the computer application.

\section{References}

[1] Birrul, dkk. Sistem Pendukung Keputusan Pemilihan Perguruan Tinggi dan Jurusan Berbasis Web Menggunakan Metode Topsis, Jurusasan System Informasi, Kanjuruhan Malang

[2] Dewi. 2015. Perencanaan System Pendukung Keputusan Untuk Penerimaan Beasiswa di SMA PGRI 1 Talang Padang Dengan Model Fuzzy Multiple Atribut Menggunakan Metode Simple Additive Weighting (SAW), Pringsewu STMIK Pringsewu.

[3] Firdausa, dkk 2016. Model System Pendukung Keputusan Pemilihan Sekolah Menggunakan Metode SAW,JurusanTeknik Informatika, Stmik Amikom Yoyakarta.

[4] Hidayat, muafiq,2016.System Pendukung Keputusan Untuk Pemilihan Hotel Dengan Simple Additive Weighting (SAW) Berbasis Web, Jurusan Teknik Informatika,STMIK AMIKOM Yogyakarta.

[5] Muslihudin, 2015. Decision Support System Penilaian Kinerja Karyawan Pada Perusahaan Menggunakan Metode Simple Additive Weighting, Jurnal TAM, Vol. 5

[6] Adela, A., Jasmi, K.A., Basiron, B., Huda, M., Maseleno, A. (2018). Selection of dancer member using simple additive weighting. International Journal of Engineering \& Technology. 7(3). 1096-1107. https://doi.org/10.14419/ijet.v7i3.11983.

[7] Aminin, S., Huda, M., Ninsiana, W., and Dacholfany, M.I. (2018). Sustaining civic-based moral values: Insights from language learning and literature. International Journal of Civil Engineering and Technology. 9(4), 157-174

[8] Amin, M.M., Nugratama, M.A.A., Maseleno, A., Huda, M., Jasmi, K.A., (2018). Design of cigarette disposal blower and automatic freshner using mq-5 sensor based on atmega 8535 microcontroller. International Journal of Engineering \& Technology. 7(3). 11081113 https://doi.org/10.14419/ijet.v7i3.11917.

[9] Atmotiyoso, P. and Huda, M. (2018). Investigating Factors Influencing Work Performance on Mathematics Teaching: A Case Study. International Journal of Instruction. 11(3), 391-402 https://doi.org/10.12973/iji.2018.11327a .

[10] Huda, M., \& Teh, K. S. M. (2018). Empowering Professional and Ethical Competence on Reflective Teaching Practice in Digital Era. In Dikilitas, K., Mede, E., Atay D. (Eds). Mentorship Strategies in
Teacher Education (pp. 136-152). Hershey, PA: IGI Global. https://doi.org/10.4018/978-1-5225-4050-2.ch007.

[11] Huda, M., Teh, K.S.M., Nor, N.H.M., and nor, M.B.M. (2018a). Transmitting Leadership Based Civic Responsibility: Insights from Service Learning. International Journal of Ethics and Systems, 34(1), 20-31. https://doi.org/10.1108/IJOES-05-2017-0079.

[12] Huda, M., Maseleno, A., Muhamad, N.H.N., Jasmi, K.A., Ahmad, A., Mustari, M.I., Basiron, B. (2018b). Big Data Emerging Technology: Insights into Innovative Environment for Online Learning Resources. International Journal of Emerging Technologies in Learning 13(1), 23-36. https://doi.org/10.3991/ijet.v13i01.6990.

[13] Huda, M., Maseleno, A., Teh, K.S.M., Don, A.G., Basiron, B., Jasmi, K.A., Mustari, M.I., Nasir, B.M., and Ahmad, R. (2018c). Understanding Modern Learning Environment (MLE) in Big Data Era. International Journal of Emerging Technologies in Learning. 13(5), 71-85. https://doi.org/10.3991/ijet.v13i05.8042.

[14] Huda, M. (2018b). Empowering Application Strategy in the Technology Adoption: Insights from Professional and Ethical Engagement. Journal of Science and Technology Policy Management. doi.org/10.1108/JSTPM-09-2017-0044.

[15] Huda. M. \& Sabani, N. (2018). Empowering Muslim Children's Spirituality in Malay Archipelago: Integration between National Philosophical Foundations and Tawakkul (Trust in God). International Journal of Children's Spirituality, 23(1), 81-94. https://doi.org/10.1080/1364436X.2018.1431613.

[16] Huda, M., Qodriah, S.L., Rismayadi, B., Hananto, A., Kardiyati, E.N., Ruskam, A., and Nasir, B.M. (2018). Towards Cooperative with Competitive Alliance: Insights into Performance Value in Social Entrepreneurship in Creating Business Value and Competitive Advantage with Social Entrepreneurship. (pp.294). Hershey, PA: IGI Globa.

[17] Huda, M., Hehsan, A., Basuki, S., Rismayadi, B., Jasmi, K. A., Basiron, B., \& Mustari, M. I. (2019). Empowering Technology Use to Promote Virtual Violence Prevention in Higher Education Context. In Intimacy and Developing Personal Relationships in the Virtual World (pp. 272-291). Hershey, PA: IGI Global. https://doi.org/10.4018/978-1-5225-4047-2.ch015.

[18] [Huda, M., Ulfatmi, Luthfi, M.J., Jasmi, K.A., Basiron, B., Mustari, M.I., Safar, A., Embong, H.W.H., Mohamad, A.M., and Mohamed, A.K. (2019). Adaptive online learning technology: Trends in big data era in Diverse Learning Opportunities Through TechnologyBased Curriculum Design. Hershey, PA: IGI Global. (In press).

[19] Kurniasih, D., Jasmi, K.A., Basiron, B., Huda, M., Maseleno, A. (2018). The uses of fuzzy logic method for finding agriculture and livestock value of potential village. International Journal of Engi$\begin{array}{llll}\text { neering } \quad \& \quad \text { Technology. } & \text { 7(3). 1091-1095. }\end{array}$ https://doi.org/10.14419/ijet.v7i3.11984.

[20] Maseleno, A., Pardimin, Huda, M., Ramlan, Hehsan, A., Yusof, Y.M., Haron, Z., Ripin, M.N., nor, N.H.M., and Junaidi, J. (2018a). Mathematical Theory of Evidence to Subject Expertise Diagnostic. ICIC Express Letters, 12 (4), 369 DOI: 10.24507/icicel.12.04.369

[21] Maseleno, A., Huda, M., Jasmi, K.A., Basiron, B., Mustari, I., Don, A.G., and Ahmad, R. (2018b). Hau-Kashyap approach for student's level of expertise. Egyptian Informatics Journal, https://doi.org/10.1016/j.eij.2018.04.001.

[22] Maseleno, A., Sabani, N., Huda, M., Ahmad, R., Jasmi, K.A., Basiron, B. (2018c). Demystifying Learning Analytics in Personalised Learning. International Journal of Engineering \& Technology. 7(3). 1124-1129. https://doi.org/10.14419/ijet.v7i3.9789.

[23] Moksin, A. I., Shahrill, M., Anshari, M., Huda, M., \& Tengah, K. A. (2018b). The Learning of Integration in Calculus Using the Autograph Technology. Advanced Science Letters, 24(1), 550-552. https://doi.org/10.1166/asl.2018.12067

[24] Putra, D.A.D., Jasmi, K.A., Basiron, B., Huda, M., Maseleno, A., Shankar, K., Aminudin, N. (2018). Tactical Steps for EGovernment Development. International Journal of Pure and Applied Mathematics.119 (15). 2251-2258

[25] Rosli, M.R.B., Salamon, H.B., and Huda, M. (2018). Distribution Management of Zakat Fund: Recommended Proposal for Asnaf Riqab in Malaysia. International Journal of Civil Engineering and Technology 9(3), pp. 56-64.

[26] Sugiyarti, E., Jasmi, K.A., Basiron, B., Huda, M., Shankar, K., Maseleno, A. (2018). Decision support system of scholarship grantee selection using data mining. International Journal of Pure and Applied Mathematics. 119 (15), 2239-2249.

[27] Sundari, E., Jasmi, K.A., Basiron, B., Huda, M., and Maseleno, A. (2018). Web-Based Decision Making System for Assessment of Employee Revenue using Weighted Product. International Journal of Engineering and Technology. 
[28] Susilowati, T., Jasmi, K.A., Basiron, B., Huda, M., Shankar, K. Maseleno, A., Julia, A., Sucipto. (2018). Determination of Scholarship Recipients Using Simple Additive Weighting Method. International Journal of Pure and Applied Mathematics.119 (15), 22312238.

[29] Anshari, M., Almunawar, M. N., Shahrill, M., Wicaksono, D. K., \& Huda, M. (2017). Smartphones usage in the classrooms: Learning aid or interference Education and Information Technologies, 22(6), 3063-3079. https://doi.org/10.1007/s10639-017-9572-7.

[30] Huda, M., Sabani, N., Shahrill, M., Jasmi, K. A., Basiron, B., \& Mustari, M. I. (2017a). Empowering Learning Culture as Student Identity Construction in Higher Education. In A. Shahriar, \& G. Syed (Eds.), Student Culture and Identity in Higher Education (p. 160-179). Hershey, PA: IGI Global. https://doi.org/10.4018/978-15225-2551-6.ch010.

[31] Huda, M., Jasmi, K. A., Hehsan, A., Shahrill, M., Mustari, M. I., Basiron, B., \& Gassama, S. K. (2017b). Empowering Children with Adaptive Technology Skills: Careful Engagement in the Digital Information Age. International Electronic Journal of Elementary Education, 9(3), 693-708.

[32] Huda, M., Shahrill, M., Maseleno, A., Jasmi, K. A., Mustari, I., \& and Basiron, B. (2017c). Exploring Adaptive Teaching Competencies in Big Data Era. International Journal of Emerging Technologies in Learning, 12(3), 68-83. https://doi.org/10.3991/ijet.v12i03.6434.

[33] Huda, M., Jasmi, K. A., Basiran, B., Mustari, M. I. B., \& Sabani, A N. (2017d). Traditional Wisdom on Sustainable Learning: An Insightful View From Al-Zarnuji's Ta 'lim al-Muta 'allim. SAGE Open, 7(1), 1-8. https://doi.org/10.1177/2158244017697160.

[34] Huda, M., Jasmi, K. A., Embong, W. H., Safar, J., Mohamad, A. M., Mohamed, A. K., Muhamad, N. H., Alas, Y., \& Rahman, S. K. (2017e). Nurturing Compassion-Based Empathy: Innovative Approach in Higher Education. In M. Badea, \& M. Suditu (Eds.), Violence Prevention and Safety Promotion in Higher Education Settings (pp. 154-173). Hershey, PA: IGI Global. https://doi.org/10.4018/978-1-5225-2960-6.ch009.

[35] Huda, M., Jasmi, K. A., Alas, Y., Qodriah, S. L., Dacholfany, M. I., \& Jamsari, E. A. (2017f). Empowering Civic Responsibility: Insights From Service Learning. In S. Burton (Ed.), Engaged Scholarship and Civic Responsibility in Higher Education(pp. 144165). Hershey, PA: IGI Global. https://doi.org/10.4018/978-1-52253649-9.ch007.

[36] Huda, M., Jasmi, K. A., Mustari, M. I., Basiron, B., Mohamed, A K., Embong, W., ... \& Safar, J. (2017g). Innovative E-Therapy Service in Higher Education: Mobile Application Design. International Journal of Interactive Mobile Technologies, 11(4), 83-94. https://doi.org/10.3991/ijim.v11i4.6734.

[37] Huda, M., Jasmi, K. A., Mustari, M. I., \& Basiron, B. (2017h). Understanding Divine Pedagogy in Teacher Education: Insights from Al-zarnuji's Ta'lim Al-Muta'Allim. The Social Sciences, 12(4), 674-679.

[38] Huda, M., Jasmi, K. A., Mustari, M. I. B., \& Basiron, A. B. (2017i) Understanding of Wara' (Godliness) as a Feature of Character and Religious Education. The Social Sciences, 12(6), 1106-1111.

[39] Huda, M., Siregar, M., Ramlan, Rahman, S.K.A., Mat Teh, K.S., Said, H., Jamsari, E.A., Yacub, J., Dacholfany, M.I., \& Ninsiana, W. (2017j). From Live Interaction to Virtual Interaction: An Exposure on the Moral Engagement in the Digital Era. Journal of Theoretical and Applied Information Technology , 95(19), 49644972.

[40] Huda, M., Maseleno, A., Jasmi, K. A., Mustari, I., \& Basiron, B. (2017k). Strengthening Interaction from Direct to Virtual Basis: Insights from Ethical and Professional Empowerment. International Journal of Applied Engineering Research, 12(17), 6901-6909.

[41] Huda, M., Haron, Z., Ripin, M. N., Hehsan, A., \& Yaacob, A. B. C. (20171). Exploring Innovative Learning Environment (ILE): Big Data Era. International Journal of Applied Engineering Research, 12(17), 6678-6685

[42] Maseleno, A., Huda, M., Siregar, M., Ahmad, R., Hehsan, A., Haron, Z., Ripin, M.N., Ihwani, S.S., and Jasmi, K.A. (2017) Combining the Previous Measure of Evidence to Educational Entrance Examination. Journal of Artificial Intelligence 10(3), 8590. https://doi.org/10.3923/jai.2017.85.90.

[43] Huda, M., Anshari, M., Almunawar, M. N., Shahrill, M., Tan, A. Jaidin, J. H., \& Masri, M. (2016a). Innovative Teaching in Higher Education: The Big Data Approach. The Turkish Online Journal of Educational Technology, 15(Special issue), 1210-1216.

[44] Huda, M., Yusuf, J. B., Jasmi, K. A., \& Nasir, G. A. (2016b). Understanding Comprehensive Learning Requirements in the Light of
al-Zarnūjī’s Ta‘līm al-Muta'allim. Sage Open, 6(4), 1-14. https://doi.org/10.1177/2158244016670197.

[45] Huda, M., Yusuf, J. B., Jasmi, K. A., \& Zakaria, G. N. (2016c). AlZarnūjī's Concept of Knowledge ('ilm). SAGE Open, 6(3), 1-13. https://doi.org/10.1177/2158244016666885.

[46] Huda, M., Jasmi, K. A., Mohamed, A. K., Wan Embong, W. H., \& and Safar, J. (2016d). Philosophical Investigation of Al-Zarnuji's Ta'lim al-Muta'allim: Strengthening Ethical Engagement into Teaching and Learning. Social Science, 11(22), 5516-551.

[47] Kartanegara, M., \& Huda, M. (2016). Constructing Civil Society: An Islamic Cultural Perspective. Mediterranean Journal of Social Science, 7(1), 126-135.

[48] Othman, R., Shahrill, M., Mundia, L., Tan, A., \& Huda, M. (2016). Investigating the Relationship between the Student's Ability and Learning Preferences: Evidence from Year 7 Mathematics Students. The New Educational Review, 44(2), 125-138.

[49] Rizky, 2014. Sitem Pendukung Keputusan Pemilihan Atlet Yang Layak Masuk Tim Pencak Silat Dengan Metode Simple Additive Weighting $(S A W)$,Jurusan Teknik Informatika, Universitas Brawijaya.

[50] Samsuri, 2014.System Pendukung Keputusan Untuk Menentukan Relawan Terbaik di PMI Kota Bengkulu Menggunakan Metode Simple Additive Weighting (SAW), Jurusan Teknik Informatika, Universitas Dehasen Bengklu.

[51] Sarah, 2014.System Pendukung Keputusan Pemilihan Mahasiswa Terbaik Untuk Memperoleh Mahasiswa Terbaik Dengan Metode Simple Additive Weighting, Jurusan Teknik Informaika, STMIK BUDIDARMA Medan.

[52] Wulandari, Aminin, S., Dacholfany, M.I., Mujib, A., Huda, M., Nasir, B.M., Maseleno, A., Sundari, E., Fauzi, Masrur, M., Design of Library Information Systems. International Journal of Engineering and Technology (UAE) (In Press).

[53] Susilowati, T., Teh, K.S.T., Nasir, B.M., Don, A.G., Huda, M., Hensafitri, T., Maseleno, A., Oktafianto, Irawan, D. Learning Application of Lampung Language Based on Multimedia Software. International Journal of Engineering and Technology (UAE) (In Press).

[54] Abadi, S., Teh, K.S.M., Nasir, B.M., Huda, M., Ivanova, N.L., Sari, T.I., Maseleno, A., Satria, F., Muslihudin, M. Application Model of K-Means Clustering Insights into Promotion Strategy of Vocational High School. International Journal of Engineering and Technology (UAE) (In Press).

[55] Susilowati, T., Dacholfany, M.I., Aminin, S., Ikhwan, A., Nasir, B.M., Huda, M., Prasetyo, A., Maseleno, A., Satria, F., Hartati, S., Wulandari. Getting Parents Involved in Child's School: Using Attendance Application System Based on SMS Gateway. International Journal of Engineering and Technology (UAE) (In Press).

[56] Aminudin, N., Huda, M., Ihwani, S.S., Noor, S.S.M., Basiron, B., Jasmi, K.A., Safar, J., Mohamed, A.K., Embong, W.H.W., Mohamad, A.M., Maseleno, A., Masrur, M., Trisnawati, Rohmadi, D. The Family Hope Program using AHP Method. International Journal of Engineering and Technology (UAE) (In Press).

[57] Aminudin, N., Fauzi, Huda, M., Hehsan, A., Ripin, M.N., Haron, Z., Junaidi, J., Irviani, R., Muslihudin, M., Hidayat, S., Maseleno, A., Gumanti, M., Fauzi, A. Application Program Learning Based on Android for Students' Experiences. International Journal of Engineering and Technology (UAE) (In Press)

[58] Abadi, S., Teh, K.S.M., Huda, M., Hehsan, A., Ripin, M.N., Haron, Z., Muhamad, N.H.N., Rianto, R., Maseleno, A., Renaldo, R., Syarifudin, A. Design of student score application for assessing the most outstanding student at vocational high school. International Journal of Engineering and Technology (UAE) (In Press).

[59] Anggraeni, E.Y., Huda, M., Maseleno, A., Safar, J., Jasmi, K.A., Mohamed, A.K., Hehsan, A., Basiron, B., Ihwani, S.S., Embong, W.H.W., Mohamad, A.M., Noor, S.S.M., Fauzi, A., Wijaya, D.A., Masrur, M. Poverty Level Grouping using SAW Method. International Journal of Engineering and Technology (UAE) (In Press).

[60] Abadi, S., Huda, M., Jasmi, K.A., Noor, S.S.M., Safar, J., Mohamed, A.K., Embong, W.H.W., Mohamad, A.M., Hehsan, A., Basiron, B., Ihwani, S.S., Maseleno, A., Muslihudin, M., Satria, F., Irawan, D., Hartati, S. Determination of the Best Quail Eggs using Simple Additive Weighting. International Journal of Engineering and Technology (UAE) (In Press)

[61] Abadi, S., Huda, M., Hehsan, A., Mohamad, A.M., Basiron, B., Ihwani, S.S., Jasmi, K.A., Safar, J., Mohamed, A.K., Embong, W.H.W., Noor, S.S.M., Brahmono, B., Maseleno, A., Fauzi, A. Aminudin, N., Gumanti, M. Design of online transaction model on traditional industry in order to increase turnover and benefits. International Journal of Engineering and Technology (UAE) (In Press). 
[62] Abadi, S., Huda, M., Basiron, B., Ihwani, S.S., Jasmi, K.A., Hehsan, A., Safar, J., Mohamed, A.K., Embong, W.H.W., Mohamad, A.M., Noor, S.S.M., Novita, D., Maseleno, A., Irviani, R., Idris, M., Muslihudin, M. Implementation of Fuzzy Analytical Hierarchy Process on Notebook Selection. International Journal of Engineering and Technology (UAE) (In Press). 